\title{
Desain Model Database Layanan Panti Werdha dengan Menerapkan Metode Database Life Cycle
}

\author{
http://dx.doi.org/10.28932/jutisi.v6i3.3047
}

\author{
Stefanus Setyo Wibagso ${ }^{\bowtie}$, Enjel Lia ${ }^{\# 2}$ \\ Program Studi Sistem Informasi,Universitas Katolik Musi Charitas \\ Jalan Bangau No.60, Palembang \\ ${ }^{1}$ setyo.wibagso@ukmc.ac.id \\ enjel.liaa24@gmail.com
}

\begin{abstract}
A nursing home is a place where the elderly get care services to live out their parenthood. In the management of nursing homes, many activities are carried out such as nursing services for the elderly, family visit activities, receiving donor assistance, managing elderly contributions, and transferring the elderly. Most of the information about these activities is still referred to manually and some of it is processed using separate applications. The aim of this research is to design the database model needed by the nursing home. The database model design can later be used as a reference for software developers in building an integrated nursing home information system. The form of research carried out is in the form of case studies with data collection methods through interview techniques and documentation studies. Meanwhile, for the analysis and design of the database model itself, it uses Database Life Cycle (DBLC) method which focuses on conceptual database design, logical database design, and physical database design. The result of this design is a relational database consisting of 11 tables and 12 relations. This research is a development from previous research with the same type where the previous research produced 7 tables with 6 relations.
\end{abstract}

Keywords - Database; Nursing Home; Database Life Cycle.

\section{Pendahuluan}

Panti werdha atau biasa disebut juga sebagai panti jompo merupakan tempat dimana para lansia mendapatkan perawatan untuk menjalani masa tuanya. Di panti werdha, para lansia tidak merasa kesepian dan bahagia dikarenakan mereka bisa bersosialiasi dengan rekan-rekan sebayanya. Beragam aktivitas dan kegiatan yang ada di dalam panti membuat para lansia menjadi lebih aktif dan bugar. Para lansia mendapatkan perawatan kesehatan yang baik melalui fasilitas perawatan intensif, pengobatan dan perhatian khusus dari pengelola panti.

Terlepas dari segala kelebihan yang diberikan oleh panti werdha, terdapat beberapa hal yang menjadi catatan bagi para lansia maupun keluarganya. Sebagian besar panti werdha memiliki aturan bahwa para lansia tidak bisa dikunjungi setiap hari oleh para tamu sehingga menyebabkan keluarga hanya bisa berkunjung sesuai dengan jadwal kunjungan yang diperbolehkan oleh pengelola panti. Di samping itu tidak semua layanan diberikan secara gratis sehingga diperlukan biaya ekstra bagi keluarga untuk menitipkan orang tuanya ke panti.

Jika mengacu pada pola aktivitas layanan lansia yang terjadi di dalam panti, maka sudah seharusnya media berbasis teknologi komputer dilibatkan untuk mendukung proses pendokumentasian data agar dapat lebih efektif. Basis data merupakan salah satu pilihan tepat untuk menggantikan media pengelolaan informasi yang dilakukan secara manual. Basis data memiliki kemampuan sebagai media penyimpanan untuk menampung banyak data dengan waktu pengaksesan yang lebih cepat serta memberikan kemudahan kontrol data seperti untuk melakukan penambahan, pengambilan, penyimpanan dan modifikasi data [1]. Melalui studi pendahuluan di salah satu panti werdha, didapatkan fakta bahwa hampir sebagian besar catatan mengenai tindakan perawatan terhadap lansia dilakukan dengan menggunakan kertas. Hasil dokumentasi riwayat tindakan perawatan menjadi sangat rawan hilang atau rusak mengingat hanya mengandalkan dokumentasi dalam bentuk hard copy.

Masalah yang dihadapi dalam merancang basis data layanan panti werdha adalah bagaimana membuat model basis data yang diperlukan untuk mengelola serta menampung data sesuai dengan kebutuhan. Untuk mengatasi permasalahan tersebut, metode perancangan basis data menjadi hal yang sangat penting karena langkah perancangan yang baik tentunya akan menghasilkan fungsi basis data yang baik pula.

Penelitian ini akan menggunakan metode perancangan basis data DBLC (Database Life Cycle). DBCL memiliki kemampuan untuk menghasilkan bentuk basis data yang efektif dan efisien karena berfokus pada rancangan basis data relasional. Relasi data sendiri berguna untuk meminimalisir terjadinya redundansi data atau duplikasi data yang tersimpan di dalam basis data. Redudansi 
memiliki kekurangan yang menyebabkan data menjadi inkonsisten sehingga pada akhirnya akan mengurangi ruang penyimpanan basis data pada hard disk. Hasil yang ingin dicapai dari penelitian ini adalah untuk menghasilkan rancangan model basis data layanan panti werdha yang lebih rinci dan detil dengan menggunakan metode DBLC.

\section{TINJAUAN PUSTAKA}

\section{A. Penelitian Terdahulu}

Kraugusteeliana menggunakan metode DBLC dalam merancang basis data untuk mendukung pengembangan aplikasi monitoring peralatan dan bahan praktikum pada lab patologi klinik FK UPNVJ [2]. Aplikasi yang dikembangkan digunakan untuk memonitor dan melaporkan kondisi alat dan bahan praktikum sehingga pekerjaan kepala laboratorium menjadi terbantu terutama untuk mengatur kelancaran proses belajar mengajar.

Nofiyani dalam penelitiannya yang berjudul " Model Basis Data untuk Mendukung Sistem Administrasi Pelayanan dan Perbaikan Motor " mengungkapkan bahwa metode DBLC mendukung perancangan basis data yang baik sehingga menghasilkan aplikasi yang baik pula. Selain itu mendukung optimalisasi kinerja dari sistem manajemen basis data itu sendiri [3].

Atanasia dan Gusti Syarifudin melakukan perancangan basis data relasional lansia di panti jompo Graha Kasih Bapa Kabupaten Kubu Raya dengan menggunakan metode DBLC. Perancangan basis data tersebut menghasilkan desain 7 tabel yang membantu pengguna dalam menyimpan, menampilkan dan memanipulasi data yang ada pada panti jompo tersebut [1].

Sharazita Dyah Anggita mengimplementasikan metode DBLC untuk merancang basis data sistem rekam medis rawat jalan puskemas. Perancangan tersebut menghasilkan desain tabel, kolom, tipe data dan constraint yang dapat menjadi acuan bagi pengembang untuk mengimplementasikannya kedalam sistem rekam medis rawat jalan. Penggunaan constraint pada struktur kolom dapat bermanfaat dalam mengurangi kesalahan pencatatan berkas serta menjaga konsistensi akan data yang diolah [4].

Erly Krisnanik dan Kraugusteeliana dalam penelitiannya yang berjudul “ Perancangan Model Basis Data Berbasis Pakar Gangguan Rahim dan Kesehatan Janin pada Wanita Hamil" mengungkapkan bahwa untuk merancang model basis data yang baik diperlukan tahapan-tahapan yang sistematis mulai dari perancangan model konseptual, perancangan skema basis data dan perancangan model fisik basis data [5].

Febria Sri Handayani dan Meidyan Permata Putri dalam penelitiannya yang berjudul "Perancangan Basis Data Instrumen Bimbingan Konseling Alat Ungkap Pemahaman Diri Siswa " mengimplementasikan DBLC untuk merancang basis data yang menjadi salah satu instrument dalam pengembangan aplikasi manajemen data pada unit bimbingan konseling di sekolah [6].

\section{B. Panti Werdha}

Panti werdha atau panti jompo merupakan rumah dimana orang jompo atau lansia diurus dan diberikan perawatan [7]. Lansia diberikan perawatan agar merasa aman sehingga dapat menghilangkan rasa gelisah dan cemas dalam menghadapi masa tuanya. Terdapat beberapa layanan yang diberikan oleh panti werdha salah satunya yaitu layanan dalam bentuk kesehatan yang dibutuhkan oleh lansia [8] Lansia atau lanjut usia adalah seseorang yang telah mencapai usia 60 tahun sehingga perlu diberikan layananan sebagai bentuk upaya membantu para lansia dalam memulihkan dan mengembalikan fungsi sosialnya [9].

Menurut Kurniawati, tujuan dari panti werdha adalah untuk menampung lansia yang tidak memiliki tempat tinggal memiliki masalah dalam keluarganya [10]. Selain dari itu panti werdha memiliki beberapa fungsi diantaranya:

1. Sebagai tempat pelayanan penunjang kesejahteraan lansia.

2. Sebagai tempat dimana lansia mendapatkan kesempatan untuk untuk beraktivitas.

3. Membantu lansia untuk menikmati masa tuanya melalui pemberian fasilitas-fasilitas pendukung.

\section{Basis Data}

Menurut Date, basis data atau database adalah sekumpulan data yang mewakili berbagai macam entitas beserta dengan hubungannya yang dirancang untuk memenuhi kebutuhan informasi untuk keperluan sebuah organisasi [11]. Penggunaan basis data memungkinan data dapat disimpan dalam jumlah yang besar serta dapat diakses secara bersamaan oleh banyak pengguna [12]. Di dalam basis data terdapat banyak entitas yang terdiri dari beragam atribut serta memiliki hubungan logis antar entitas. Kumpulan data pada database diatur secara terorganisir dan memiliki relasi antar data. Tujuan utamanya adalah untuk mendukung kemudahan berinteraksi dan meningkatkan kecepatan terhadap pemrosesan data yang diolah [13].

\section{Metode DBLC (Database Life Cycle)}

Basis data sesuai dengan konsep DBLC (Database Life Cycle) adalah konsep perancangan basis data yang berfokus basis data relasional [14]. Metode DBLC merupakan metode yang menjelaskan mengenai siklus hidup dari basis data. Siklus yang terjadi pada DBLC akan terus kembali ketitik awal oleh karena basis data mengalami perubahan sesuai dengan perkembangan kebutuhan. Proses utama dalam mendesain basis data terbagi menjadi tiga tahapan, yaitu perancangan basis data konseptual (conceptual scheme design), perancangan logikal (logical design), dan perancangan fisikal (phisycal design) [15]. Sebelum masuk kedalam tahapan desain terdapat beberapa tahapan awal yang harus dilakukan [13] yaitu:

1. Perencanaan Basis Data (Database Planning) : Tahap ini merupakan tahap awal dalam menentukan tujuan dari basis data yang akan dibuat (Mission Statement) dan menentukan fungsi apa saya yang bisa dilakukan oleh 
basis data.

2. Pendefinisian Sistem (System Definition) : Pada tahap ini dilakukan identifikasi user view pada basis data berdasarkan perannya masing-masing.

3. Analisis dan Pengumpulan Kebutuhan (Requirement Collection and Analysis) : Tahap selanjutnya adalah tahapan untuk menganalisis dan mengumpulkan kebutuhan apa saja yang dibutuhkan untuk membangun basis data yang diharapkan.

Terdapat tiga tahap dalam perancangan basis data yang dilakukan yaitu meliputi [16] :

1. Desain Basis Data Konseptual (Conceptual Scheme Design) : Tahap perancangan untuk menentukan siapa saja yang terlibat dalam sistem, apa saja input yang diperlukan, informasi (output) apa yang diinginkan dari basis data.

2. Desain Logikal Objek Basis Data (Logical Design) : Tahapan dimana dilakukan perancangan database logical yang dimulai dari penentuan entitas (data object) dan atribut (field) kemudian dilanjutkan dengan perancangan ERD (Entity Relationship Diagram). ERD atau Diagram ER-D digunakan sebagai teknik pendekatan yang menggambarkan adanya hubungan sebuah model. ERD digunakan untuk menunjukan hubungan (relationship) antar entitas pada sebuah basis data [4].

3. Desain Fisik Basis Data (Phisycal Design) : Tahap ini merupakan tahapan transformasi dari perancangan logis kedalam bentuk fisik ke dalam media penyimpanan menggunakan DBMS (Database Management System).

Setelah tahap perancangan model fisik dilanjutkan dengan tahap implementasi yang terdiri dari implementasi basis data dan implementasi tabel. Tahap implementasi merupakan bentuk dari perwujudan atau realisasi basis data kedalam pemrograman melalui penggunaan Bahasa SQL (Structured Query Language) [12]. Tahapantahapan lengkap mengenai perancangan basis data dengan metode DBLC dapat dilihat dari pada gambar 1.

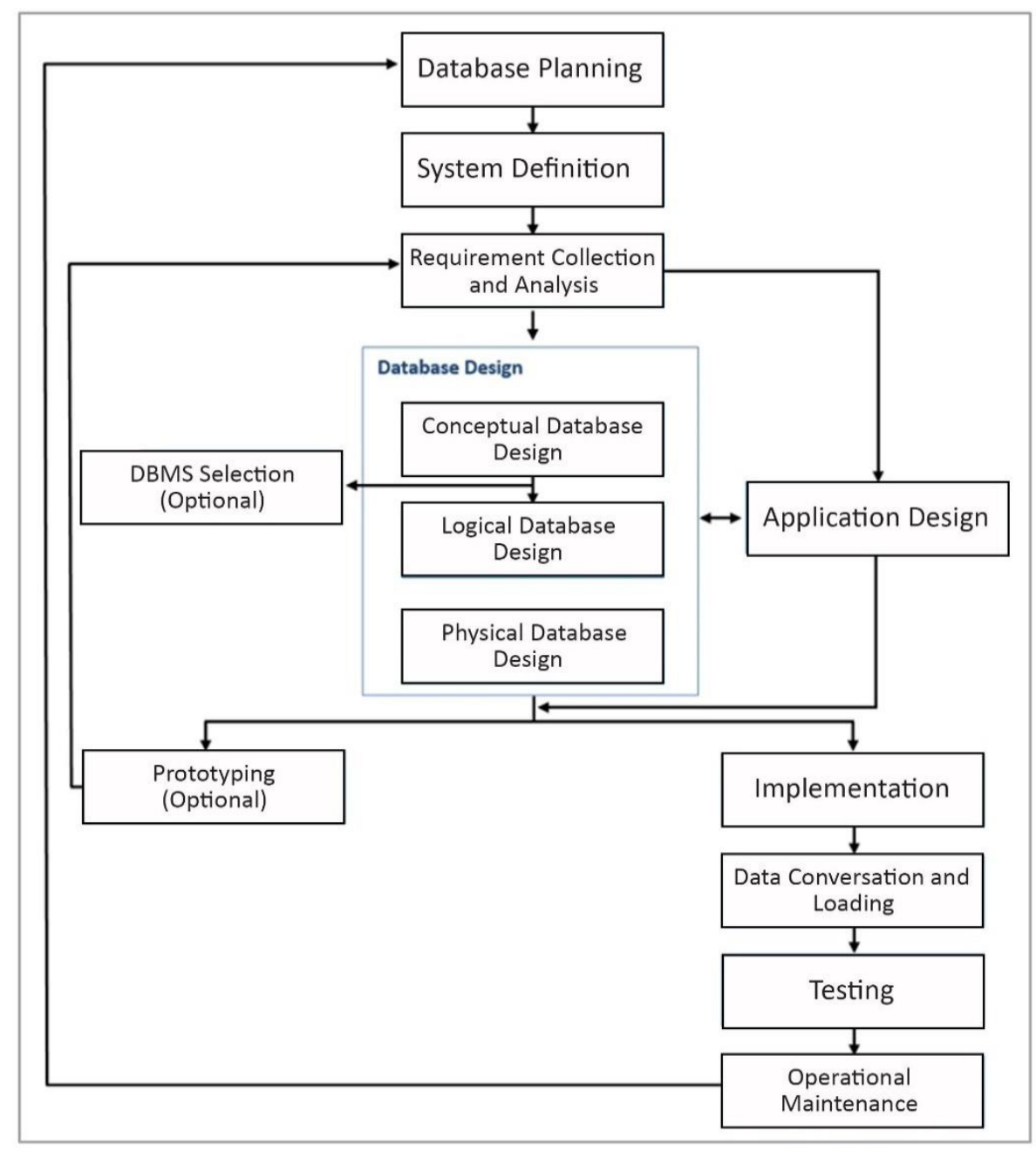

Gambar 1. Metode DBLC. 


\section{METODOLOGI}

Permasalahan yang dihadapi dalam perancangan model basis data layanan panti werdha adalah bagaimana membangun basis data yang sesuai dengan kebutuhan operasional layanan. Untuk itu dalam penelitian ini dilakukan beberapa tahapan yang menjadi solusi pemecahan masalah perancangan model basis tersebut. Tahapan itu diantaranya:

\section{A. Pengumpulan Data}

\section{Kepustakaan :}

Kepustakaan dilakukan oleh penulis untuk memperoleh informasi terkait dengan penelitian yang dilakukan. Sumber pustaka bersumber dari data sekunder seperti buku, jurnal, artikel dan situs di internet.

\section{Wawancara}

Teknik wawancara dilakukan dengan cara mengajukan pertanyaan petugas administrasi dan perawat pada panti werdha. Wawancara dilakukan untuk menggali informasi tentang analisis kebutuhan data yang diperlukan. Hasil wawancara menjadi bahan pertimbangan yang sangat penting karena dapat memberikan gambaran secara nyata tentang alur proses informasi yang terjadi di panti.

\section{Studi dokumentasi}

Studi dokumentasi dilakukan untuk mengumpulkan informasi dari data fisik yang ada pada objek yang diteliti.

\section{B. Perancangan Basis Data Menggunakan Motode DBLC}

Dalam penelitian ini akan dilakukan perancangan basis data layanan Panti Werdha dengan menggunakan metode DBLC. Tidak semua tahapan pada metode DBLC dijalankan karena output dari perancangan ini hanya sebatas pada menghasilkan model basis data relasional. Gambaran kegiatan yang dilakukan pada di tiap tahapan perancangan ditunjukkan pada gambar 2 .

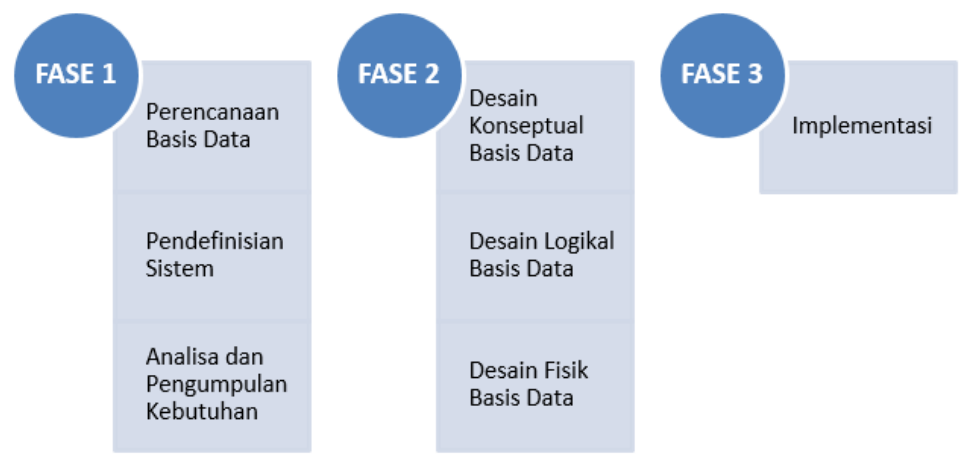

Gambar 2. Perancangan Basis Data dengan Metode DBLC.

Fase 1

- Perencanaan Basis Data (Database Planning).
Pada tahap paling awal akan dilakukan perencanaan basis data terkait tujuan dan fungsi dari pengelolaan data menggunakan basis data bagi pengelola panti werdha. Perencanaan ini melibatkan otoritas yang berwenang di panti tersebut melalui wawancara tatap muka secara langsung dengan petugas administrasi dan perawat panti wedha.

- Pendefinisian Sistem (System Definition).

Pada tahap ini dilakukan identifikasi pengguna yang terlibat didalam layanan panti werdha terkait pengelolaan data berdasarkan pada perannya masingmasing.

- Analisis dan Pengumpulan Kebutuhan (Requirement Collection and Analysis).

Pada tahap ini dilakukan analisis dan pengumpulan informasi terkait kebutuhan apa saja yang dibutuhkan untuk membangun basis data melalui pengamatan langsung ke panti werdha maupun referensi dari sumber lainnya seperi jurnal pendukung dan informasiinformasi website yang merujuk pada layanan panti werdha.

Fase 2

- Desain Basis Data Konseptual (Conceptual Scheme Design).

Langkah yang dilakukan pada tahap ini adalah merancang input data dan output informasi yang diperlukan oleh basis data berdasarkan pada hasil identifikasi pengguna yang terlibat di dalam sistem.

- Desain Desain Logikal Objek Basis Data (Logical Design).

Pada tahapan desain logikal objek basis data dilakukan perancangan database logical yang dimulai dari penentuan entitas dan atribut kemudian dilanjutkan dengan perancangan ERD (Entity Relationship Diagram) pada basis data layanan panti werdha.

- Desain Fisik Basis Data (Phisycal Design).

Pada tahap ini dilakukan proses transformasi dari hasil perancangan logis basis data yang telah dirancang sebelumnya kedalam bentuk fisik. Media yang akan digunakan untuk penyimpanan data adalah DMBS (Database Management System) MySql.

Fase 3

Implementasi.

Pada tahap ini dilakukan realisasi basis data melalui pembuatan basis data dan tabel dengan menggunakan tool phpMyAdmin. PhpyMyAdmin berfungsi untuk mempermudah spembuatan basis data, tabel dan perancangan ERD pada DBMS MySql. Tool ini membantu menyederhanakan penggunaan baris perintah bahasa SQL (Structured Query Language) yang berisi fitur DDL (Data Defintion Language) dan DML (Data Manipulation Language) melalui tampilan antar muka berbasis grafis. 


\section{HASIL DAN PEMBAHASAN}

\section{A. Perancangan Basis Data}

Fase 1

- Perencanaan Basis Data (Database Planning). Melalui wawancara tatap muka langsung yang melibatkan petugas administrasi dan perawat panti werdha, didapatkan hasil bahwa basis data yang dirancang harus dapat digunakan untuk menyimpan informasi yang terjadi di dalam panti. Informasi tersebut meliputi data lansia, data iuran, data sumbangan, data kunjungan lansia, data pegawai, data menu makanan lansia, dan riwayat kesehatan lansia.

- Pendefinisian Sistem (System Definition).

Desain basis data panti werdha dirancang untuk menyimpan informasi terkait aktifitas layanan yang diberikan kepada lansia serta kebutuhan informasi lain yang dibutuhkan oleh panti. Terdapat beberapa aktor yang berperan dalam sistem pada panti werdha. Peran aktor tersebut dapat dilihat pada tabel I.

TABEL I

Pendefinisan Pengguna Berdasarkan Kebutuhan

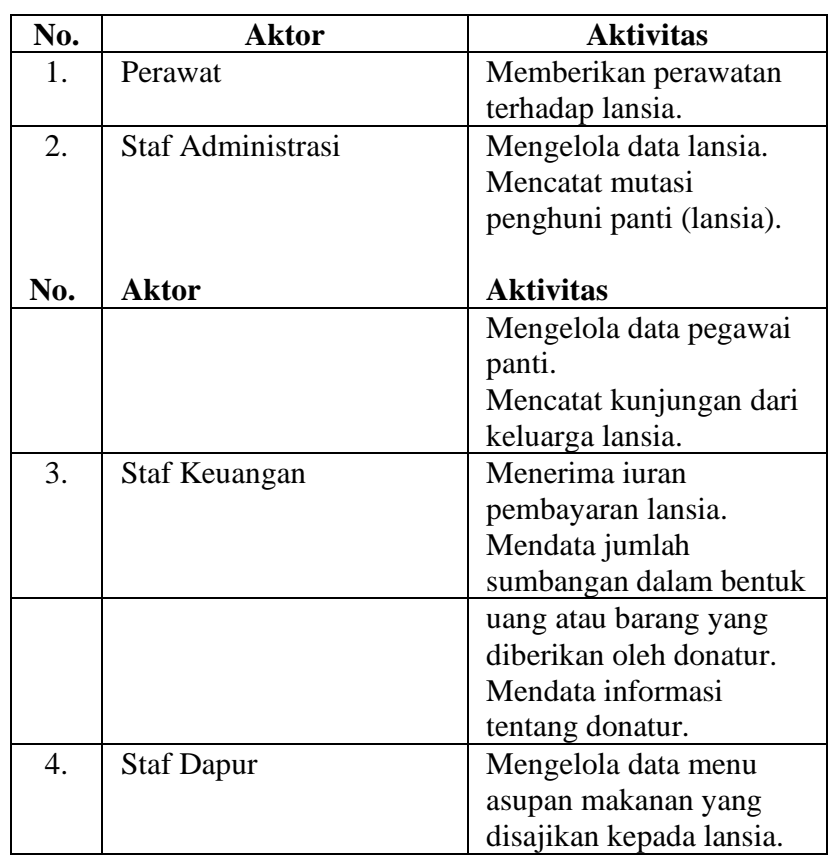

- Analisis dan Pengumpulan Kebutuhan (Requirement Collection and Analysis)

Hasil dari analisis kebutuhan yang didapatkan melalui pengamatan dan wawancara langsung dengan pihak panti werdha adalah sebagai berikut :

1. Analisis Kebutuhan Informasi.

Pengelola panti werdha menghadapi beberapa kesulitan dalam memonitor aktivitas yang terjadi di dalam panti. Kesulitan tersebut diantaranya :
- Mendapatkan informasi secara detil mengenai perawatan terhadap lansia terutama mengenai riwayat tindakan kesehatan setiap lansia.

- Membuat menu makanan variatif yang sangat berguna bagi asupan gizi lansia.

- Catatan kunjungan lansia dan data sumbangan dari donatur belum terdokumentasi dengan baik.

- Membuat laporan yang baik terhadap data dari masing-masing bagian.

- Data masih tersimpan secara terpisah dengan menggunakan aplikasi yang berbeda serta sebagian pencatatan masih disimpan dalam bentuk hard copy sehingga rentan untuk rusak.

Atas dasar permasalahan yang terjadi diatas maka diperlukan basis data yang digunakan untuk penyimpanan data dimana sewaktu-waktu data tersebut dapat diakses kembali untuk proses pembuatan laporan.

2. Analisis Kebutuhan Penyimpanan Data.

Dikarenakan sebagian data dalam bentuk hard copy rentan akan kerusakan dan data-data lain tersimpan dalam media penyimpanan yang berbeda-beda maka peneliti menyarankan kepada pengelola untuk menggunakan aplikasi basis data sebagai media penyimpanan tunggal yang berfungsi mengintegrasikan semua data dari terkait aktivitas yang terjadi di panti werdha.

\section{Analisis Kebutuhan Teknologi.}

Terdapat beragam media yang digunakan dalam pengelolaan informasi di panti werdha, mulai dari media konvensional sampai dengan menggunakan aplikasi spread sheet dan words processor. Namun demikian pengelola masih mengalami kendala dalam proses pengelolaanya dikarenakan semua masih diolah secara terpisah. Oleh sebab itu pemilihan teknologi yang tepat menjadi solusi dalam meningkatkan efektifitas pengelolaan data sehingga pada akhirnya menghasilkan kualitas informasi yang semakin baik dan bermanfaat bagi panti.

Fase 2

- Desain Basis Data Konseptual (Conceptual Scheme Design).

Tahap ini merupakan tahapan dimana model data konseptual dirancang sesuai dengan kebutuhan data panti werdha. Terdapat 2 kegiatan didalamnya yaitu identifikasi tipe entitas dan identifikasi tipe relasional. 1. Identifikasi Tipe Entitas.

Tipe entitas yang dibutuhkan akan diperoleh melalui identifikasi entitas berdasarkan daftar aktivitas pengguna yang mengacu pada kata benda yang terdapat didalamnya. Hasil dari proses identifikasi tipe entitas dapat dilihat pada tabel II. 
TABEL III

IDENTIFIKASI TIPE ENTITAS

\begin{tabular}{|c|c|c|c|}
\hline No. & $\begin{array}{c}\text { Nama } \\
\text { Entitas }\end{array}$ & Deskripsi & Kegiatan \\
\hline 1. & $\begin{array}{l}\text { perawatan_1 } \\
\text { ansia }\end{array}$ & $\begin{array}{l}\text { Entitas yang } \\
\text { berisikan } \\
\text { informasi terkait } \\
\text { perawatan } \\
\text { kesehatan } \\
\text { terhadap lansia. }\end{array}$ & $\begin{array}{l}\text { Semua tindakan } \\
\text { perawatan yang } \\
\text { dilakukan kepada } \\
\text { lansia. }\end{array}$ \\
\hline 2. & lansia & $\begin{array}{l}\text { Entitas yang } \\
\text { berisikan data } \\
\text { lansia. }\end{array}$ & $\begin{array}{l}\text { Semua lansia } \\
\text { yang menghuni di } \\
\text { panti werdha. }\end{array}$ \\
\hline 3. & $\begin{array}{l}\text { mutasi_lansi } \\
\text { a }\end{array}$ & $\begin{array}{l}\text { Entitas yang } \\
\text { berisikan } \\
\text { informasi terkait } \\
\text { mutasi lansia. }\end{array}$ & $\begin{array}{l}\text { Semua mutasi } \\
\text { lansia yang } \\
\text { terjadi di panti } \\
\text { werdha. }\end{array}$ \\
\hline 4. & pegawai & $\begin{array}{l}\text { Entitas yang } \\
\text { berisikan data } \\
\text { pegawai panti. }\end{array}$ & $\begin{array}{l}\text { Semua pegawai } \\
\text { yang bekerja di } \\
\text { panti werdha. }\end{array}$ \\
\hline 5. & kunjungan & $\begin{array}{l}\text { Entitas yang } \\
\text { berisikan } \\
\text { informasi } \\
\text { kunjungan } \\
\text { keluarga lansia. }\end{array}$ & $\begin{array}{l}\text { Setiap kali } \\
\text { adanya kunjungan } \\
\text { keluarga lansia }\end{array}$ \\
\hline 6. & iuran & $\begin{array}{l}\text { Entitas yang } \\
\text { berisikan data } \\
\text { pembayaran iuran } \\
\text { layanan panti. }\end{array}$ & $\begin{array}{l}\text { Setiap } \\
\text { pembayaran iuran } \\
\text { yang dilakukan } \\
\text { atas nama } \\
\text { masing-masing } \\
\text { lansia. }\end{array}$ \\
\hline 7. & $\begin{array}{l}\text { sumbangan_ } \\
\text { uang }\end{array}$ & $\begin{array}{l}\text { Entitas yang } \\
\text { berisikan data } \\
\text { sumbangan yang } \\
\text { diberikan oleh } \\
\text { donatur dalam } \\
\text { bentuk uang. }\end{array}$ & $\begin{array}{l}\text { Setiap sumbangan } \\
\text { dalam bentuk } \\
\text { uang yang } \\
\text { diberikan oleh } \\
\text { donatur. }\end{array}$ \\
\hline 8. & $\begin{array}{l}\text { sumbangan_ } \\
\text { barang }\end{array}$ & $\begin{array}{l}\text { Entitas yang } \\
\text { berisikan data } \\
\text { sumbangan yang } \\
\text { diberikan oleh } \\
\text { donatur dalam } \\
\text { bentuk barang. } \\
\end{array}$ & $\begin{array}{l}\text { Setiap sumbangan } \\
\text { dalam bentuk } \\
\text { barang yang } \\
\text { diberikan oleh } \\
\text { donatur. }\end{array}$ \\
\hline 9. & $\begin{array}{l}\text { detil_sumba } \\
\text { ngan_baran } \\
\mathrm{g}\end{array}$ & $\begin{array}{l}\text { Entitas yang } \\
\text { berisikan detil } \\
\text { data sumbangan } \\
\text { barang yang } \\
\text { diberikan oleh } \\
\text { masing-masing } \\
\text { donatur. }\end{array}$ & $\begin{array}{l}\text { Setiap sumbangan } \\
\text { dalam bentuk } \\
\text { barang yang } \\
\text { diberikan oleh } \\
\text { donatur. }\end{array}$ \\
\hline 10. & donatur & $\begin{array}{l}\text { Entitas yang } \\
\text { berisikan data } \\
\text { donatur. }\end{array}$ & $\begin{array}{l}\text { Setiap donatur } \\
\text { yang telah } \\
\text { menyumbang. }\end{array}$ \\
\hline 11. & menu_lansia & $\begin{array}{l}\text { Entitas yang } \\
\text { berisikan } \\
\text { informasi terkait } \\
\text { data menu asupan } \\
\text { makanan yang } \\
\text { akan disajikan } \\
\text { kepada lansia. }\end{array}$ & $\begin{array}{l}\text { Semua menu } \\
\text {.asupan makanan } \\
\text { yang akan } \\
\text { diberikan kepada } \\
\text { lansia. }\end{array}$ \\
\hline
\end{tabular}

2. Identifikasi Tipe Relasional.

Identifkasi tipe relasional bertujuan untuk menentukan hubungan penting antar entitas yang sebelumnya telah didapatkan dari proses identifikasi. Hasil identifikasi mendapatkan bahwa terdapat entitas yang mempunyai hubungan ke satu kejadian pada entitas yang lainnya. Hal ini terlihat dari tipe relasi satu ke banyak yang ditunjukkan melalui notasi $1 . . *$. Berikut daftar entitas beserta penjelasan mengenai relasinya yang diperlihatkan pada tabel III.

TABEL IIIII

IDENTIFIKASI TIPE RELASIONAL

\begin{tabular}{|c|c|c|c|}
\hline $\begin{array}{l}\text { Nama } \\
\text { Entitas }\end{array}$ & $\begin{array}{l}\text { Tipe } \\
\text { Relasi }\end{array}$ & Nama Entitas & Deskripsi \\
\hline \multirow[t]{2}{*}{ lansia } & $\begin{array}{l}1 . . * \\
1 . . *\end{array}$ & $\begin{array}{l}\text { iuran } \\
\text { kunjungan }\end{array}$ & $\begin{array}{l}\text { Lansia bisa } \\
\text { menerima lebih dari } \\
\text { satu kali tindakan } \\
\text { perawatan kesehatan. } \\
\text { Lansia bisa lebih dari } \\
\text { satu kali melakukan } \\
\text { pembayaran iuran } \\
\text { layanan panti. } \\
\text { Lansia bisa lebih dari } \\
\text { satu kali menerima } \\
\text { kunjungan. }\end{array}$ \\
\hline & $1 .{ }^{*}$ & mutasi_lansia & $\begin{array}{l}\text { Mutasi lansia bisa } \\
\text { terjadi lebih dari satu } \\
\text { kali. }\end{array}$ \\
\hline \multirow[t]{2}{*}{ pegawai } & 1..* & perawatan_lansia & $\begin{array}{l}\text { Pegawai bisa } \\
\text { memberikan } \\
\text { tindakan perawatan } \\
\text { kesehatan lebih dari } \\
\text { satu kali. } \\
\text { Pegawai bisa } \\
\text { menerima iuran } \\
\text { layanan lebih dari } \\
\text { satu kali. }\end{array}$ \\
\hline & 1..* & $\begin{array}{l}\text { sumbangan_uang } \\
\text { sumbangan_baran } \\
\text { g }\end{array}$ & $\begin{array}{l}\text { Pegawai bisa } \\
\text { membuat menu } \\
\text { asupan makanan } \\
\text { lansia lebih dari satu } \\
\text { kali. } \\
\text { Pegawai bisa } \\
\text { menerima } \\
\text { sumbangan uang } \\
\text { lebih dari satu kali. } \\
\text { Pegawai bisa } \\
\text { menerima } \\
\text { sumbangan barang } \\
\text { lebih dari satu kali. }\end{array}$ \\
\hline $\begin{array}{l}\text { sumban } \\
\text { gan_bar } \\
\text { ang }\end{array}$ & $1 .{ }^{*}$ & $\begin{array}{l}\text { detil_sumbangan_ } \\
\text { barang. }\end{array}$ & $\begin{array}{l}\text { Satu kali penerimaan } \\
\text { sumbangan dalam } \\
\text { bentuk barang dapat } \\
\text { diterima lebih dari } \\
\text { satu item. }\end{array}$ \\
\hline donatur & $1 .{ }^{*}$ & sumbangan_uang & $\begin{array}{l}\text { Donatur dapat lebih } \\
\text { dari satu kali } \\
\text { berdonasi dalam } \\
\text { bentuk barang. }\end{array}$ \\
\hline
\end{tabular}




\begin{tabular}{|l|l|l|l|}
\hline $\begin{array}{l}\text { Nama } \\
\text { Entitas }\end{array}$ & $\begin{array}{l}\text { Tipe } \\
\text { Relasi }\end{array}$ & Nama Entitas & Deskripsi \\
\hline & $1 .{ }^{*}$ & $\begin{array}{l}\text { Sumbangan_baran } \\
\mathrm{g}\end{array}$ & $\begin{array}{l}\text { Donatur dapat lebih } \\
\text { dari satu kali } \\
\text { berdonasi dalam } \\
\text { bentuk barang. }\end{array}$ \\
\hline
\end{tabular}

- Desain Desain Logikal Objek Basis Data (Logical Design).

Pada tahap selanjutnya dilakukan perancangan database logical yang dimulai dari identifikasi atribut beserta dengan kandidat key yang akan digunakan pada tiap entitas. Fungsi dari penentuan key dari masing-masing entitas digunakan untuk kebutuhan perancangan relasi antar entitas (primary key dan foreign key). Primary key merupakan kunci utama atau field kunci pada sebuah tabel yang menjadi acuan untuk mendefinisikan sebuah baris data. Sementara foreign key merupakan suatu field bagian dari tabel yang menunjukkan hubungan (relasi) ke tabel induknya.

Setelah itu dilanjutkan ke tahap normalisasi terhadap entitas dengan tujuan untuk menghindari inkonsistensi desain basis data relasional akibat dari redudansi data yang bisa timbul karena adanya atribut-atribut yang kembar. Hasil dari identifikasi atribut dan candidat key dapat dilihat pada tabel IV.

TABEL IVV

IDENTIFIKASI ATRIBUT DAN KANDIDAT KEY

\begin{tabular}{|c|c|c|c|}
\hline No. & $\begin{array}{l}\text { Nama } \\
\text { Entitas }\end{array}$ & Atribut & Kandidat Key \\
\hline 1. & $\begin{array}{l}\text { perawatan_la } \\
\text { nsia }\end{array}$ & $\begin{array}{l}\text { KdTindakan } \\
\text { TglTindakan } \\
\text { KdLansia } \\
\text { Nip } \\
\text { Keluhan } \\
\text { Tindakan } \\
\text { Keterangan } \\
\end{array}$ & KdTindakan \\
\hline 2. & lansia & $\begin{array}{l}\text { KdLansia } \\
\text { NoKTP } \\
\text { TglMasuk } \\
\text { Nama } \\
\text { JK } \\
\text { TempatLahir } \\
\text { TglLahir } \\
\text { Agama } \\
\text { Status } \\
\text { NamaPJ } \\
\text { Alamat } \\
\text { Telpon } \\
\text { Email }\end{array}$ & KdLansia \\
\hline 3. & mutasi_lansia & $\begin{array}{l}\text { KdMutasi } \\
\text { TglMutasi } \\
\text { KdLansia } \\
\text { Alasan } \\
\text { Keterangan }\end{array}$ & KdMutasi \\
\hline
\end{tabular}

\begin{tabular}{|c|c|c|c|}
\hline No. & $\begin{array}{l}\text { Nama } \\
\text { Entitas }\end{array}$ & Atribut & Kandidat Key \\
\hline 4. & pegawai & $\begin{array}{l}\text { Nip } \\
\text { NoKTP } \\
\text { Nama } \\
\text { JK } \\
\text { TempatLahir } \\
\text { TglLahir } \\
\text { Status } \\
\text { Alamat } \\
\text { Telpon } \\
\text { TglBergabung }\end{array}$ & Nip \\
\hline 5. & kunjungan & $\begin{array}{l}\text { KdKunjungan } \\
\text { TglKunjungan } \\
\text { KdLansia } \\
\text { NamaPengunjung } \\
\text { Hubungan } \\
\text { WaktuKunjungan }\end{array}$ & KdKunjungan \\
\hline 6. & iuran & $\begin{array}{l}\text { KdPembayaran } \\
\text { TglBayar } \\
\text { KdLansia } \\
\text { Nip } \\
\text { JumlahBayar } \\
\text { Keterangan }\end{array}$ & KdPembayaran \\
\hline 7. & $\begin{array}{l}\text { sumbangan_ } \\
\text { uang }\end{array}$ & $\begin{array}{l}\text { KdSmbUang } \\
\text { TglTerima } \\
\text { Nip } \\
\text { KdDonatur } \\
\text { Metode } \\
\text { Jumlah } \\
\end{array}$ & KdSmbUang \\
\hline 8. & $\begin{array}{l}\text { sumbangan_ } \\
\text { barang }\end{array}$ & $\begin{array}{l}\text { KdSmbBarang } \\
\text { TglTerima } \\
\text { Nip } \\
\text { KdDonatur } \\
\text { Keterangan }\end{array}$ & KdSmbBarang \\
\hline 9. & $\begin{array}{l}\text { detil_sumban } \\
\text { gan_barang }\end{array}$ & $\begin{array}{l}\text { KdSmbBarang } \\
\text { NamaBarang } \\
\text { Jumlah } \\
\text { Satuan }\end{array}$ & KdSmbBarang \\
\hline 10. & donatur & $\begin{array}{l}\text { KdDonatur } \\
\text { Nama } \\
\text { Alamat } \\
\text { Telpon } \\
\text { Email } \\
\end{array}$ & KdDonatur \\
\hline 11. & menu_lansia & $\begin{array}{l}\text { KdMenu } \\
\text { Nip } \\
\text { Hari } \\
\text { Waktu } \\
\text { MenuMakanan }\end{array}$ & KdMenu \\
\hline
\end{tabular}

Berikut adalah entitas-entitas yang telah melewati proses normalisasi tahap pertama (1NF), dimana pada tahap tersebut telah ditentukan atribut primary key serta telah menghilangkan atribut-atribut yang tidak konsisten (attribute multi-valued). Tahap normalisasi selanjutnya adalah sebagai berikut :

1.Perawatan Lansia

$2 \mathrm{NF}$

perawatan_lansia $=@$ KdTindakan + TglTindakan + KdLansia + NoKTP, TglMasuk + Nama + JK + 
TempatLahir + TglLahir + Agama + Status + NamaPJ + Alamat + Telpon + Email + Nip + NoKTP + Nama + JK + TempatLahir + TglLahir + Status + Alamat + Telpon + TglBergabung + Keluhan + Tindakan + Keterangan

$3 \mathrm{NF}$

perawatan_lansia $=@$ KdTindakan + TglTindakan + \#KdLansia + \#Nip + Keluhan + Tindakan + Keterangan

lansia = @ KdLansia + NoKTP, TglMasuk + Nama $+\mathrm{JK}+$ TempatLahir + TglLahir + Agama + Status + $\mathrm{NamaPJ}+$ Alamat + Telpon + Email

pegawai = @Nip + NoKTP + Nama + JK + TempatLahir + TglLahir + Status + Alamat + Telpon + TglBergabung

\section{Mutasi Lansia}

$2 \mathrm{NF}$

mutasi_lansia $=$ @KdMutasi + TglMutasi + KdLansia + NoKTP, TglMasuk + Nama + JK + TempatLahir + TglLahir + Agama + Status + NamaPJ + Alamat + Telpon + Email + Alasan + Keterangan

$3 \mathrm{NF}$

mutasi_lansia $=$ @KdMutasi + TglMutasi + \#KdLansia + Alasan + Keterangan

lansia = @ KdLansia + NoKTP, TglMasuk + Nama + JK + TempatLahir + TglLahir + Agama + Status + $\mathrm{NamaPJ}+$ Alamat + Telpon + Email

\section{Kunjungan \\ $2 \mathrm{NF}$ \\ kunjungan = @ KdKunjungan + TglKunjungan + KdLansia + NoKTP, TglMasuk + Nama + JK + TempatLahir + TglLahir + Agama + Status + NamaPJ + Alamat + Telpon + Email + NamaPengunjung + Hubungan + WaktuKunjungan}

$3 \mathrm{NF}$

kunjungan $=@$ KdKunjungan + KdKunjungan + \#KdLansia + NamaPengunjung + Hubungan + WaktuKunjungan

lansia = @ KdLansia + NoKTP, TglMasuk + Nama $+\mathrm{JK}+$ TempatLahir + TglLahir + Agama + Status + $\mathrm{NamaPJ}+$ Alamat + Telpon + Email

\section{Iuran}

$2 \mathrm{NF}$

iuran = @ KdPembayaran + TglBayar + KdLansia + NoKTP, TglMasuk + Nama + JK + TempatLahir + TglLahir + Agama + Status + NamaPJ + Alamat +
Telpon + Email + Nip + NoKTP + Nama + JK + TempatLahir + TglLahir + Status + Alamat + Telpon + TglBergabung + JumlahBayar + Keterangan

$3 \mathrm{NF}$

iuran = @ KdPembayaran + KdPembayaran + \#KdLansia + \#Nip + JumlahBayar + Keterangan lansia = KdLansia + NoKTP, TglMasuk + Nama + JK + TempatLahir + TglLahir + Agama + Status + NamaPJ + Alamat + Telpon + Email

pegawai $=@ \mathrm{Nip}+\mathrm{NoKTP}+\mathrm{Nama}+\mathrm{JK}+$ TempatLahir + TglLahir + Status + Alamat + Telpon + TglBergabung

\section{Sumbangan Uang}

$2 \mathrm{NF}$

sumbangan_uang $=@$ KdSmbUang + TglTerima + $\mathrm{Nip}+\mathrm{NoKTP}+\mathrm{Nama}+\mathrm{JK}+$ TempatLahir + TglLahir + Status + Alamat + Telpon + TglBergabung + KdDonatur + Nama + Alamat + Telpon + Email + Metode + Jumlah

$3 \mathrm{NF}$

sumbangan_uang = @KdSmbUang + TglTerima + \#Nip + \#KdDonatur + Metode + Jumlah

pegawai = @Nip + NoKTP + Nama + JK + TempatLahir + TglLahir + Status + Alamat + Telpon + TglBergabung

donatur=@KdDonatur + Nama + Alamat + Telpon + Email

\section{Sumbangan Barang}

$2 \mathrm{NF}$

Sumbangan_barang = @ KdSmbBarang + TglTerima $+\mathrm{Nip}+\mathrm{NoKTP}+\mathrm{Nama}+\mathrm{JK}+$ TempatLahir + TglLahir + Status + Alamat + Telpon + TglBergabung + KdDonatur + Keterangan

\section{$3 \mathrm{NF}$}

sumbangan_barang = @KdSmbBarang + TglTerima + \#Nip + \#KdDonatur + Keterangan

pegawai $=@ \mathrm{Nip}+\mathrm{NoKTP}+\mathrm{Nama}+\mathrm{JK}+$ TempatLahir + TglLahir + Status + Alamat + Telpon + TglBergabung

donatur = $@$ KdDonatur + Nama + Alamat + Telpon + Email

detil_smb_barang = @ KdSmbBarang + NamaBarang + Jumlah + Satuan

\section{Menu Lansia}

2NF

menu_lansia $=@$ KdMenu + Nip + NoKTP + Nama $+\mathrm{JK}+$ TempatLahir + TglLahir + Status + Alamat + 
Telpon + TglBergabung + Hari + Waktu + MenuMakanan

$3 \mathrm{NF}$

menu_lansia = @KdMenu + \#Nip + Hari + Waktu + MenuMakanan

pegawai $=$ @Nip + NoKTP + Nama + JK + TempatLahir + TglLahir + Status + Alamat + Telpon + TglBergabung
Setelah proses normalisasi dilanjutkan dengan perancangan relasi entitas tabel yang hasilnya terlihat pada gambar 3 .

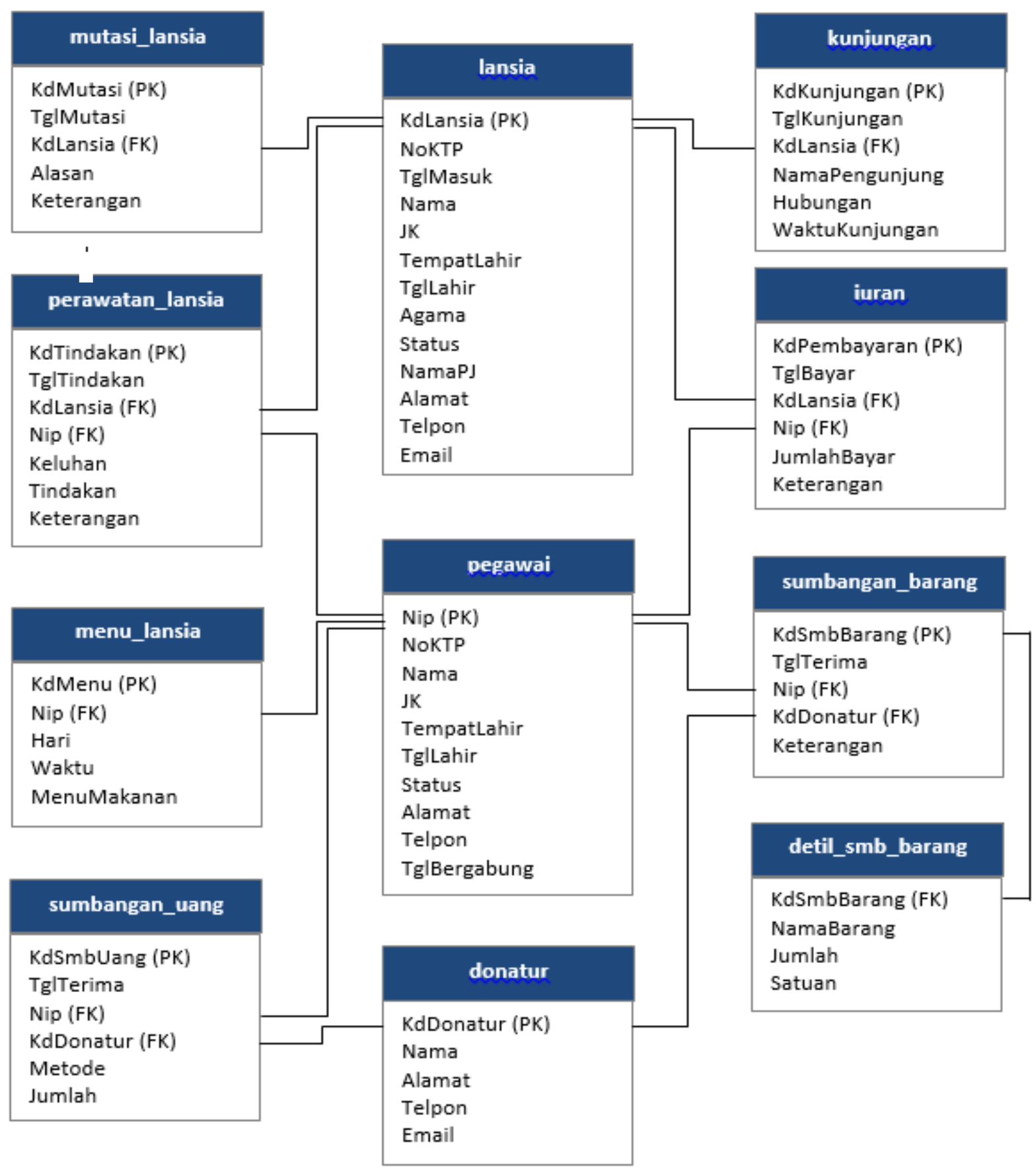

Gambar 3. Diagram Hubungan Entitas Konseptual Panti Werdha 
- Desain Fisik Basis Data (Phisycal Design).

Pada tahap desain fisik basis data dilakukan implementasi rancangan basis data logikal kedalam bentuk fisik dengan menggunakan DMBS (Database Management System) MySql. Hasil dari proses transformasi entitas dan atribut menjadi tabel dan field dalam basis data secara lengkap dapat dilihat pada tabel V sampai dengan tabel XV.

TABEL V

TABEL PERAWATAN_LANSIA

\begin{tabular}{|c|c|c|c|c|}
\hline No. & $\begin{array}{l}\text { Nama } \\
\text { Field }\end{array}$ & Tipe Data & Ukuran & Keterangan \\
\hline 1. & $\begin{array}{l}\text { KdTindak } \\
\text { an (PK) }\end{array}$ & VARCHAR & 10 & Kode tindakan \\
\hline 2. & $\begin{array}{l}\text { TglTindak } \\
\text { an }\end{array}$ & DATE & 10 & $\begin{array}{l}\text { Tanggal } \\
\text { tindakan }\end{array}$ \\
\hline 3. & KdLansia & VARCHAR & 10 & Kode lansia \\
\hline 4. & $\operatorname{Nip}(\mathrm{FK})$ & VARCHAR & 10 & $\begin{array}{l}\text { No. induk } \\
\text { pegawai }\end{array}$ \\
\hline 5. & Keluhan & VARCHAR & 150 & Keluhan \\
\hline 6. & Tindakan & VARCHAR & 150 & Tindakan \\
\hline 7. & Keterangan & VARCHAR & 150 & Keterangan \\
\hline & & $\begin{array}{r}\text { Total } \\
\text { Ukuran } \\
\end{array}$ & 150 & Byte \\
\hline & \multicolumn{4}{|c|}{ *) $P K=$ Primary Key, $F K=$ Foreign Key } \\
\hline
\end{tabular}

TABEL VI

TABEL LANSIA

\begin{tabular}{|c|l|c|c|l|}
\hline No. & $\begin{array}{l}\text { Nama } \\
\text { Field }\end{array}$ & Tipe Data & Ukuran & Keterangan \\
\hline 1. & $\begin{array}{l}\text { KdLansia } \\
(\text { PK })\end{array}$ & VARCHAR & 10 & Kode lansia \\
\hline 2. & NoKTP & VARCHAR & 17 & No. KTP \\
\hline 3. & TglMasuk & DATE & 10 & $\begin{array}{l}\text { Tanggal } \\
\text { masuk lansia }\end{array}$ \\
\hline 4. & Nama & VARCHAR & 50 & Nama lansia \\
\hline 5. & JK & VARCHAR & 10 & Jenis kelamin \\
\hline 6. & $\begin{array}{l}\text { TempatLa } \\
\text { hir }\end{array}$ & VARCHAR & 50 & Tempat lahir \\
\hline 7. & TglLahir & DATE & 10 & Tanggal lahir \\
\hline 8. & Agama & VARCHAR & 20 & Agama \\
\hline 9. & Status & VARCHAR & 20 & $\begin{array}{l}\text { Status } \\
\text { pernikahan }\end{array}$ \\
\hline 10. & NamaPJ & VARCHAR & 50 & $\begin{array}{l}\text { Nama } \\
\text { penanggung } \\
\text { jawab }\end{array}$ \\
\hline 11. & Alamat & VARCHAR & 150 & Alamat \\
\hline 12. & Telpon & VARCHAR & 17 & Telpon \\
\hline 13. & Email & VARCHAR & 50 & $\begin{array}{l}\text { Email } \\
\text { Penanggung } \\
\text { Jawab }\end{array}$ \\
\hline & & $\begin{array}{r}\text { Total } \\
\text { Unteran }\end{array}$ & $\mathbf{4 6 4}$ & \\
\hline
\end{tabular}

\begin{tabular}{|l|l|l|l|l|}
\hline No. & $\begin{array}{l}\text { Nama } \\
\text { Field }\end{array}$ & Tipe Data & Ukuran & Keterangan \\
\hline & $*) P K=$ Primary Key, FK= Foreign Key \\
\hline
\end{tabular}

TABEL VII

TABEL MUTASI_LANSIA

\begin{tabular}{|c|c|c|c|c|}
\hline No. & $\begin{array}{l}\text { Nama } \\
\text { Field } \\
\end{array}$ & Tipe Data & Ukuran & Keterangan \\
\hline 1. & $\begin{array}{l}\text { KdMutasi } \\
(\mathrm{PK})\end{array}$ & VARCHAR & 10 & $\begin{array}{l}\text { Kode mutasi } \\
\text { lansia }\end{array}$ \\
\hline 2. & TglMutasi & DATE & 10 & $\begin{array}{l}\text { Tanggal } \\
\text { mutasi. }\end{array}$ \\
\hline 3. & $\begin{array}{l}\text { KdLansia } \\
\text { (FK) }\end{array}$ & VARCHAR & 10 & Kode lansia \\
\hline 4. & Alasan & VARCHAR & 50 & Alasan mutasi \\
\hline \multirow[t]{3}{*}{5.} & Keterangan & VARCHAR & 150 & Keterangan \\
\hline & & $\begin{array}{r}\text { Total } \\
\text { Ukuran }\end{array}$ & 230 & Byte \\
\hline & \multicolumn{4}{|c|}{ *) $P K=$ Primary Key, $F K=$ Foreign Key } \\
\hline
\end{tabular}

TABEL VIII

TABEL PEGAWAI

\begin{tabular}{|c|c|c|c|c|}
\hline No. & $\begin{array}{l}\text { Nama } \\
\text { Field }\end{array}$ & Tipe Data & Ukuran & Keterangan \\
\hline 1. & Nip (PK) & VARCHAR & 10 & $\begin{array}{l}\text { No. induk } \\
\text { pegawai }\end{array}$ \\
\hline 2. & NoKTP & VARCHAR & 17 & No. KTP \\
\hline 3. & Nama & VARCHAR & 50 & $\begin{array}{l}\text { Nama } \\
\text { pegawai }\end{array}$ \\
\hline 4. & JK & VARCHAR & 10 & Jenis kelamin \\
\hline 5. & $\begin{array}{l}\text { TempatLa } \\
\text { hir }\end{array}$ & VARCHAR & 35 & Tempat lahir \\
\hline 6. & TglLahir & DATE & 10 & Tanggal lahir \\
\hline 7. & Status & VARCHAR & 15 & Status kawin \\
\hline 8. & Alamat & VARCHAR & 150 & Alamat \\
\hline 9. & Telpon & VARCHAR & 17 & Telpon \\
\hline \multirow[t]{3}{*}{10.} & $\begin{array}{l}\text { TglBergab } \\
\text { ung }\end{array}$ & VARCHAR & 10 & $\begin{array}{l}\text { Tanggal } \\
\text { pertama kerja }\end{array}$ \\
\hline & & $\begin{array}{r}\text { Total } \\
\text { Ukuran }\end{array}$ & 324 & Byte \\
\hline & \multicolumn{4}{|c|}{ *) $P K=$ Primary Key, $F K=$ Foreign Key } \\
\hline
\end{tabular}

TABEL IX

TABEL PERAWATAN_LANSIA

\begin{tabular}{|c|l|c|c|l|}
\hline No. & $\begin{array}{l}\text { Nama } \\
\text { Field }\end{array}$ & Tipe Data & Ukuran & Keterangan \\
\hline 1. & $\begin{array}{l}\text { KdKunjun } \\
\text { gan (PK) }\end{array}$ & VARCHAR & 10 & $\begin{array}{l}\text { Kode } \\
\text { kunjungan }\end{array}$ \\
\hline 2. & $\begin{array}{l}\text { TglKunjun } \\
\text { gan }\end{array}$ & DATE & 10 & $\begin{array}{l}\text { Tanggal } \\
\text { kunjungan }\end{array}$ \\
\hline 3. & $\begin{array}{l}\text { KdLansia } \\
\text { (FK) }\end{array}$ & VARCHAR & 10 & Kode lansia \\
\hline 4. & $\begin{array}{l}\text { NamaPeng } \\
\text { unjung }\end{array}$ & VARCHAR & 50 & $\begin{array}{l}\text { Nama } \\
\text { pengunjung }\end{array}$ \\
\hline 5. & Hubungan & VARCHAR & 50 & $\begin{array}{l}\text { Hubungan } \\
\text { keluarga }\end{array}$ \\
\hline
\end{tabular}




\begin{tabular}{|c|c|c|c|c|}
\hline No. & $\begin{array}{l}\text { Nama } \\
\text { Field }\end{array}$ & Tipe Data & Ukuran & Keterangan \\
\hline 6. & $\begin{array}{l}\text { WaktuKun } \\
\text { jungan }\end{array}$ & TIME & 10 & $\begin{array}{l}\text { Waktu mulai } \\
\text { kunjungan }\end{array}$ \\
\hline & & $\begin{array}{r}\text { Total } \\
\text { Ukuran }\end{array}$ & 140 & Byte \\
\hline
\end{tabular}

TABEL $X$

TABEL IURAN

\begin{tabular}{|c|c|c|c|c|}
\hline No. & $\begin{array}{l}\text { Nama } \\
\text { Field }\end{array}$ & Tipe Data & Ukuran & Keterangan \\
\hline 1. & $\begin{array}{l}\text { KdPemba } \\
\text { yaran } \\
\text { (PK) }\end{array}$ & VARCHAR & 10 & $\begin{array}{l}\text { Kode } \\
\text { pembayaran }\end{array}$ \\
\hline 2. & TglBayar & DATE & 10 & Tanggal bayar \\
\hline 3. & $\begin{array}{l}\text { KdLansia } \\
\text { (FK) }\end{array}$ & VARCHAR & 10 & Kode lansia \\
\hline 4. & $\operatorname{Nip}(F K)$ & VARCHAR & 10 & $\begin{array}{l}\text { No. induk } \\
\text { pegawai }\end{array}$ \\
\hline 5. & $\begin{array}{l}\text { JumlahBa } \\
\text { yar }\end{array}$ & VARCHAR & 7 & $\begin{array}{l}\text { Jumlah iuran } \\
\text { dibayar }\end{array}$ \\
\hline \multirow[t]{3}{*}{6.} & $\begin{array}{l}\text { Keteranga } \\
\mathrm{n}\end{array}$ & VARCHAR & 100 & Keterangan \\
\hline & & $\begin{array}{r}\text { Total } \\
\text { Ukuran }\end{array}$ & 147 & Byte \\
\hline & \multicolumn{4}{|c|}{ *) $P K=$ Primary Key, $F K=$ Foreign Key } \\
\hline
\end{tabular}

TABEL XI

TABEL SUMBANGAN_UANG

\begin{tabular}{|c|c|c|c|c|}
\hline No. & $\begin{array}{l}\text { Nama } \\
\text { Field }\end{array}$ & Tipe Data & Ukuran & Keterangan \\
\hline 1. & $\begin{array}{l}\text { KdSmbUa } \\
\text { ng (PK) }\end{array}$ & VARCHAR & 10 & $\begin{array}{l}\text { Kode } \\
\text { sumbangan } \\
\text { uang }\end{array}$ \\
\hline 2. & TglTerima & DATE & 10 & $\begin{array}{l}\text { Tanggal } \\
\text { terima }\end{array}$ \\
\hline 3. & Nip (FK) & VARCHAR & 10 & $\begin{array}{l}\text { No. induk } \\
\text { pegawai }\end{array}$ \\
\hline 4. & $\begin{array}{l}\text { KdDonatu } \\
\mathrm{r}(\mathrm{FK})\end{array}$ & VARCHAR & 10 & Kode donatur \\
\hline 5. & Metode & VARCHAR & 25 & $\begin{array}{l}\text { Metode } \\
\text { sumbangan }\end{array}$ \\
\hline 6. & Jumlah & INT & 11 & $\begin{array}{l}\text { Jumlah } \\
\text { besaran uang }\end{array}$ \\
\hline & & $\begin{array}{r}\text { Total } \\
\text { Ukuran } \\
\end{array}$ & 76 & Byte \\
\hline & \multicolumn{4}{|c|}{ *) $P K=$ Primary Key, $F K=$ Foreign Key } \\
\hline
\end{tabular}

TABEL XII

TABEL SUMBANGAN_BARANG

\begin{tabular}{|c|l|c|c|l|}
\hline No. & $\begin{array}{l}\text { Nama } \\
\text { Field }\end{array}$ & Tipe Data & Ukuran & Keterangan \\
\hline 1. & $\begin{array}{l}\text { KdSmbBa } \\
\text { rang (PK) }\end{array}$ & VARCHAR & 10 & $\begin{array}{l}\text { Kode } \\
\text { sumbangan } \\
\text { barang }\end{array}$ \\
\hline 2. & TglTerima & DATE & 10 & $\begin{array}{l}\text { Tanggal } \\
\text { terima }\end{array}$ \\
\hline No. & Nama & Tipe Data & Ukuran & Keterangan \\
\hline
\end{tabular}

\begin{tabular}{|c|l|c|c|l|}
\hline & Field & & & \\
\hline 3. & Nip (FK) & VARCHAR & 10 & $\begin{array}{l}\text { No. induk } \\
\text { pegawai }\end{array}$ \\
\hline 4. & $\begin{array}{l}\text { KdDonatu } \\
\text { (FK) }\end{array}$ & VARCHAR & 10 & Kode donatur \\
\hline 5. & Keterangan & VARCHAR & 150 & Keterangan \\
\hline & $\begin{array}{r}\text { Total } \\
\text { Ukuran }\end{array}$ & $\mathbf{1 9 0}$ & Byte \\
\hline & *) PK= Primary Key, FK= Foreign Key \\
\hline
\end{tabular}

TABEL XIII

TABEL SUMBANGAN_BARANG

\begin{tabular}{|c|c|c|c|c|}
\hline No. & $\begin{array}{l}\text { Nama } \\
\text { Field }\end{array}$ & Tipe Data & Ukuran & Keterangan \\
\hline 1. & $\begin{array}{l}\mathrm{KdSmbBa} \\
\text { rang }\end{array}$ & VARCHAR & 10 & $\begin{array}{l}\text { Kode } \\
\text { sumbangan } \\
\text { barang }\end{array}$ \\
\hline 2. & $\begin{array}{l}\text { NamaBara } \\
\text { ng }\end{array}$ & VARCHAR & 35 & Nama barang \\
\hline 3. & Jumlah & INT & 4 & Jumlah \\
\hline 4. & Satuan & VARCHAR & 20 & Satuan \\
\hline & & $\begin{array}{r}\text { Total } \\
\text { Ukuran } \\
\end{array}$ & 69 & Byte \\
\hline & \multicolumn{4}{|c|}{ *) $P K=$ Primary Key, $F K=$ Foreign Key } \\
\hline
\end{tabular}

TABEL XIV

TABEL SUMBANGAN_BARANG

\begin{tabular}{|c|c|c|c|c|}
\hline No. & $\begin{array}{l}\text { Nama } \\
\text { Field }\end{array}$ & Tipe Data & Ukuran & Keterangan \\
\hline 1. & $\begin{array}{l}\text { KdDonatu } \\
\mathrm{r}(\mathrm{PK})\end{array}$ & VARCHAR & 10 & Kode donatur \\
\hline 2. & Nama & DATE & 35 & Nama donatur \\
\hline 3. & Alamat & VARCHAR & 150 & Alamat \\
\hline 4. & Telpon & VARCHAR & 17 & Telpon \\
\hline No. & $\begin{array}{l}\text { Nama } \\
\text { Field }\end{array}$ & Tipe Data & Ukuran & Keterangan \\
\hline \multirow[t]{3}{*}{5.} & Email & VARCHAR & 35 & Email donatur \\
\hline & & $\begin{array}{r}\text { Total } \\
\text { Ukuran }\end{array}$ & 247 & Byte \\
\hline & \multicolumn{4}{|c|}{ *) $P K=$ Primary Key, $F K=$ Foreign Key } \\
\hline
\end{tabular}

TABEL XV

TABEL MENU_LANSIA

\begin{tabular}{|c|c|c|c|c|}
\hline No. & $\begin{array}{l}\text { Nama } \\
\text { Field }\end{array}$ & Tipe Data & Ukuran & Keterangan \\
\hline 1. & $\begin{array}{l}\text { KdDonatu } \\
\mathrm{r}(\mathrm{PK})\end{array}$ & VARCHAR & 10 & Kode donatur \\
\hline 2. & Nama & DATE & 35 & Nama donatur \\
\hline 3. & Alamat & VARCHAR & 150 & Alamat \\
\hline 4. & Telpon & VARCHAR & 17 & Telpon \\
\hline 5. & Email & VARCHAR & 35 & Email donatur \\
\hline & & $\begin{array}{r}\text { Total } \\
\text { Ukuran } \\
\end{array}$ & 247 & Byte \\
\hline & \multicolumn{4}{|c|}{ *) $P K=$ Primary Key, $F K=$ Foreign Key } \\
\hline
\end{tabular}


Fase 3

Implementasi.

Berdasarkan hasil dari tahap desain fisik basis data maka basis data sudah dapat direalisasikan ke dalam DMBS (Database Management System) MySql melalui tool phpMyAdmin. Terdapat 4 tahapan dalam proses membangun basis data dengan menggunakan phpMyAdmin yaitu :

1. Membuat Basis Data yang diperlihatkan pada gambar 4.

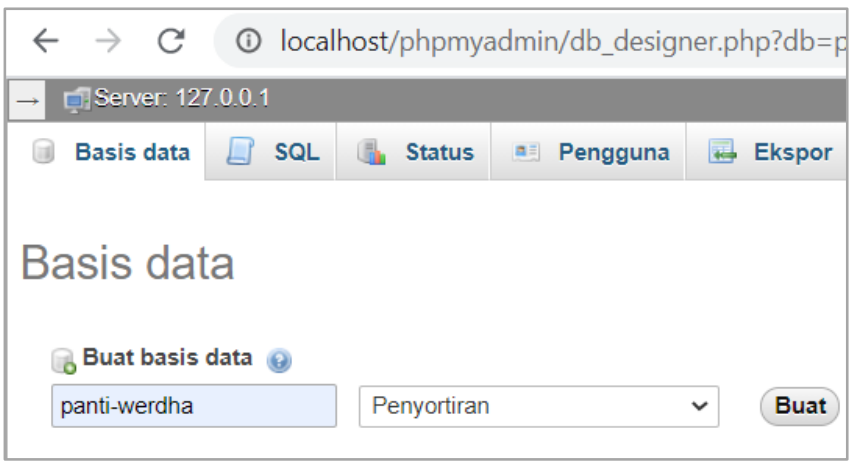

Gambar 4. Membuat Basis Data Panti Werdha Menggunakan phpMyAdmin.

2. Mendesain tabel disertai dengan memilih field utama atau primary key. Gambar 5 dibawah menunjukkan cara untuk mendesain tabel baru dengan menggunakan tool phpMyAdmin.

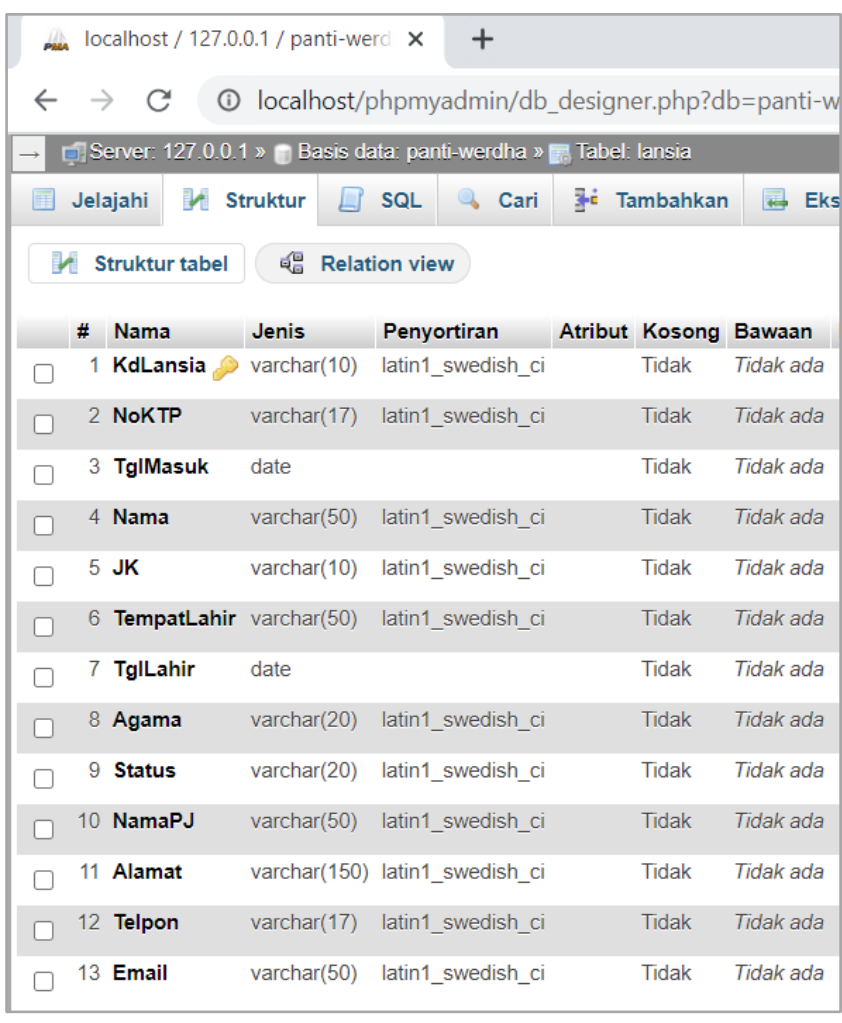

Gambar 5. Mendesain Tabel Menggunakan phpMyAdmin.

3. Membuat relasi tabel dengan menggunakan fitur desainer yang diperlihatkan pada gambar 6 .

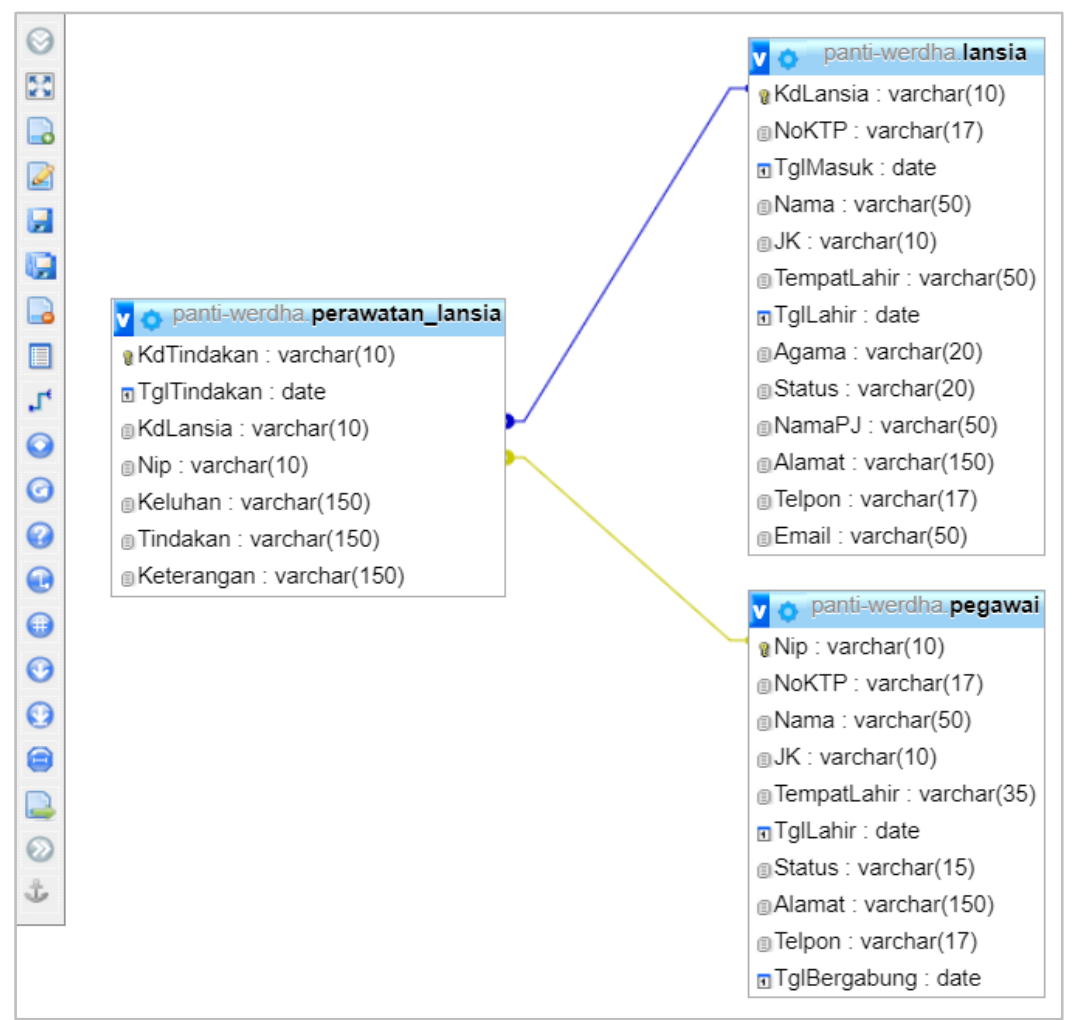

Gambar 6. Mendesain Relasi Tabel Menggunakan phpMyAdmin. 
4. Melakukan pengujian basis data.

Pada gambar 7 menunjukkan hasil proses pengujian input tabel donatur. Pengujian dilakukan dengan menggunakan 2 cara yaitu dengan menggunakan perintah query dan form input data phpMyAdmin.

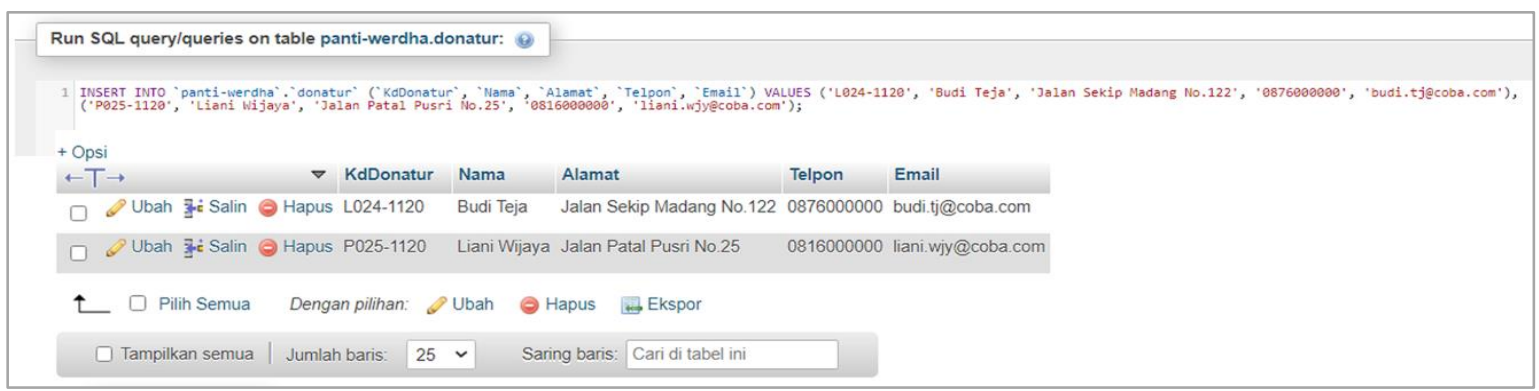

Gambar 7. Pengujian Input Data pada Tabel Donatur.

Selanjutnya dilakukan pengujian relasi tabel yang ditunjukkan pada gambar 8. Pada gambar tersebut terlihat bahwa pada form input data tabel sumbangan_barang terdapat dua input field dropdown berisikan data yang telah berelasi dengan tabel yang lain. Field Nip berelasi dengan field Nip pada tabel pegawai dan field KdDonatur berelasi dengan field KdDonatur pada tabel donatur

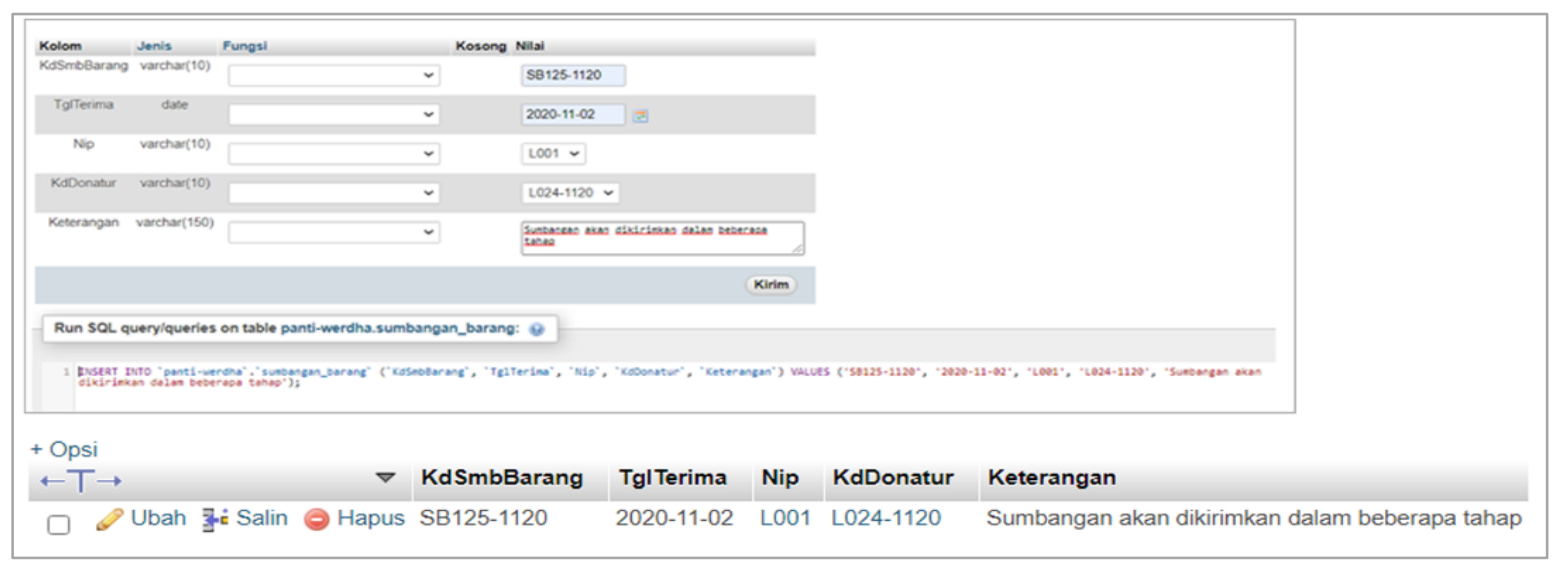

.Gambar 8. Pengujian Relasi Tabel Melalui Input Data Dropdown.

Gambar 9, 10 dan 11 menunjukkan tahapan pengujian untuk relasi tahap ketiga (3NF). Pada gambar 9 terlihat form input yang digunakan untuk memasukan data sumbangan barang dimana terdapat field KdSmbBarang sebagai primary key.

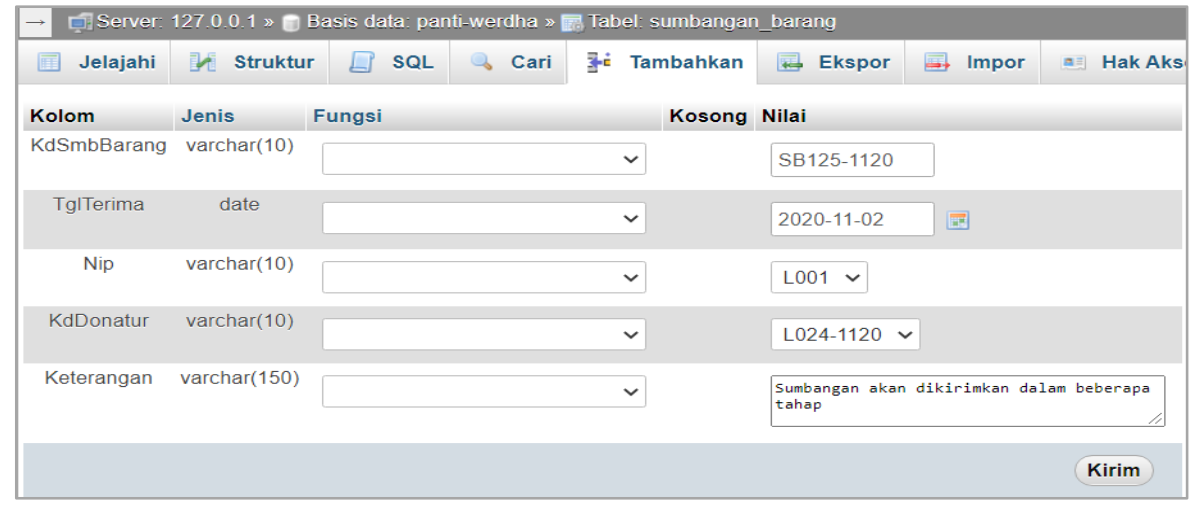

Gambar 9. Pengujian Input Data Tabel Sumbangan_Barang. 
Untuk input data detil item sumbangan barang diperlihatkan melalui form input pada gambar 10. Pada tabel tersebut terlihat bahwa field KdSmbBarang tidak diatur sebagai primary key dikarenakan fungsinya digunakan untuk menampung data kode yang sama secara berulang. Field KdSmbBarang berelasi dengan field KdSmbBarang pada tabel sumbangan_barang

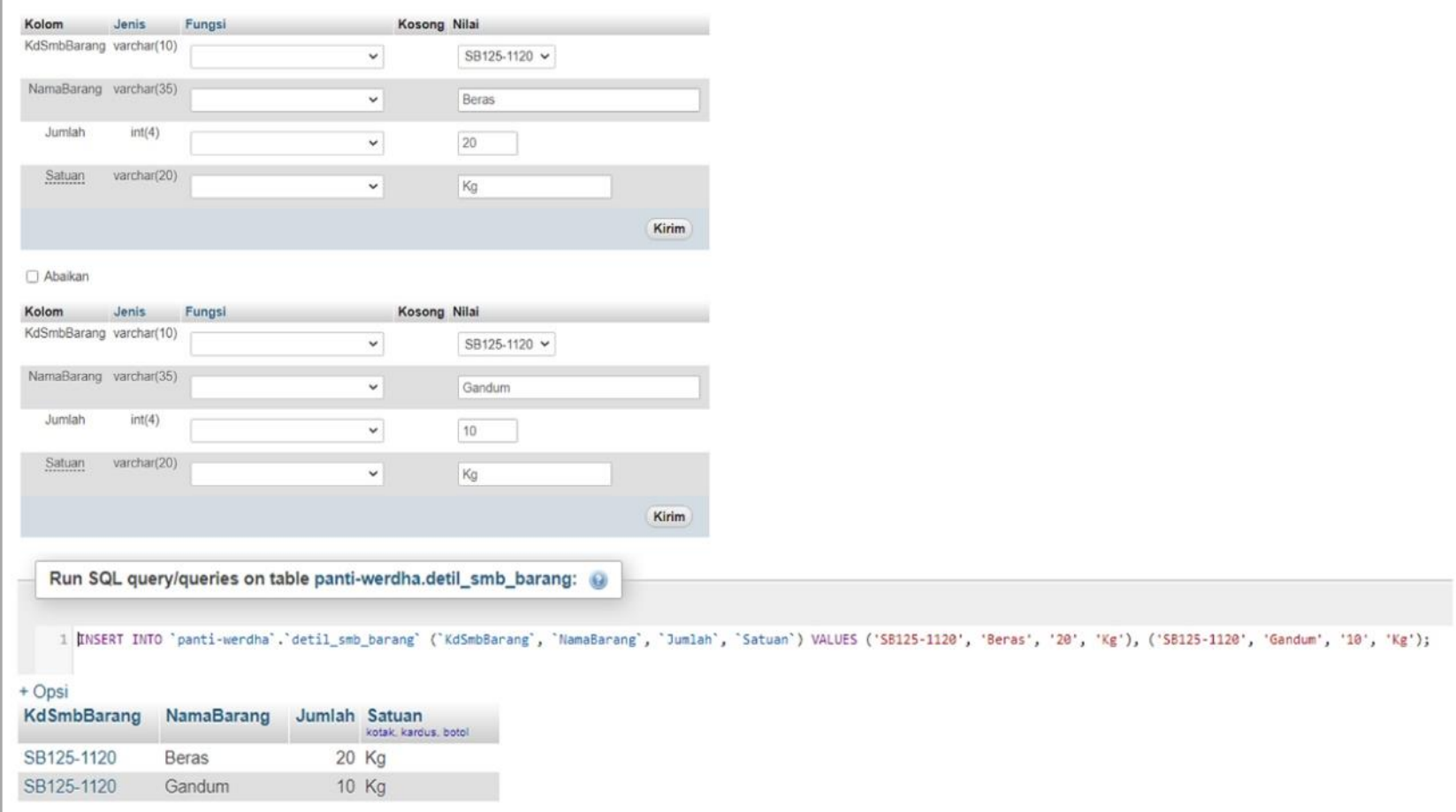

.Gambar 10. Pengujian Input Data Tabel Detil_Smb_Barang.

Hasil pengujian query untuk relasi tahap ketiga yang melibatkan tabel sumbangan_barang, detil_smb_barang, pegawai dan donator diperlihatkan pada gambar 11 dibawah ini.

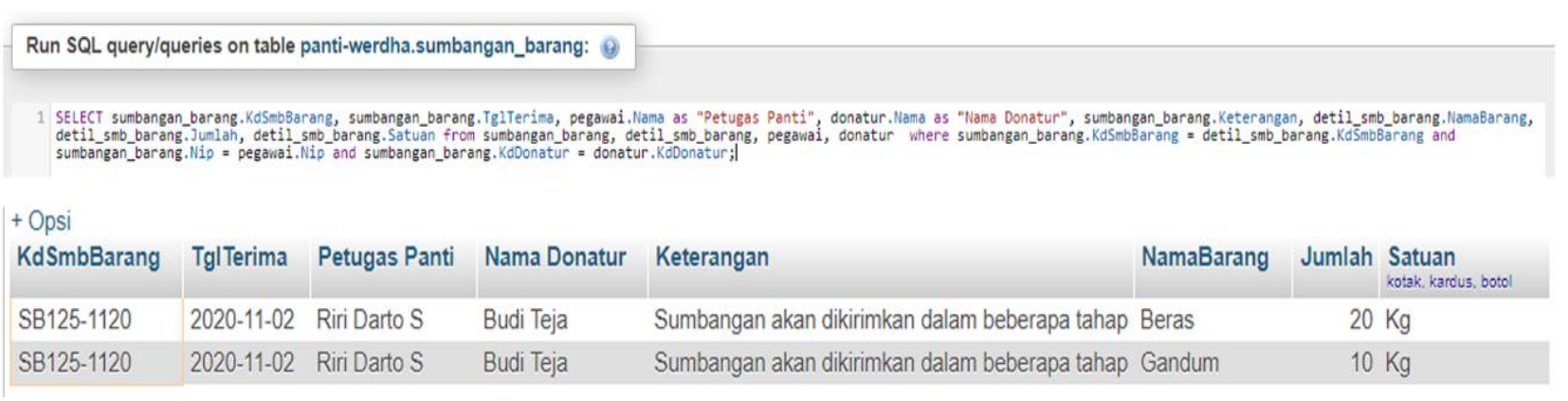

Gambar 11. Hasil Pengujian Query untuk Relasi ketiga.

\section{B. Hasil Perancangan Basis Data}

Hasil yang didapat dari perancangan basis data layanan panti werdha dengan menggunakan metode DBLC (Database Life Cycle) adalah basis data relasional yang terdiri dari 11 tabel dan 12 relasi tabel. Berikut hasil rancangan basis data layanan panti werdha yang diperlihatkan pada gambar 12 dibawah ini. 


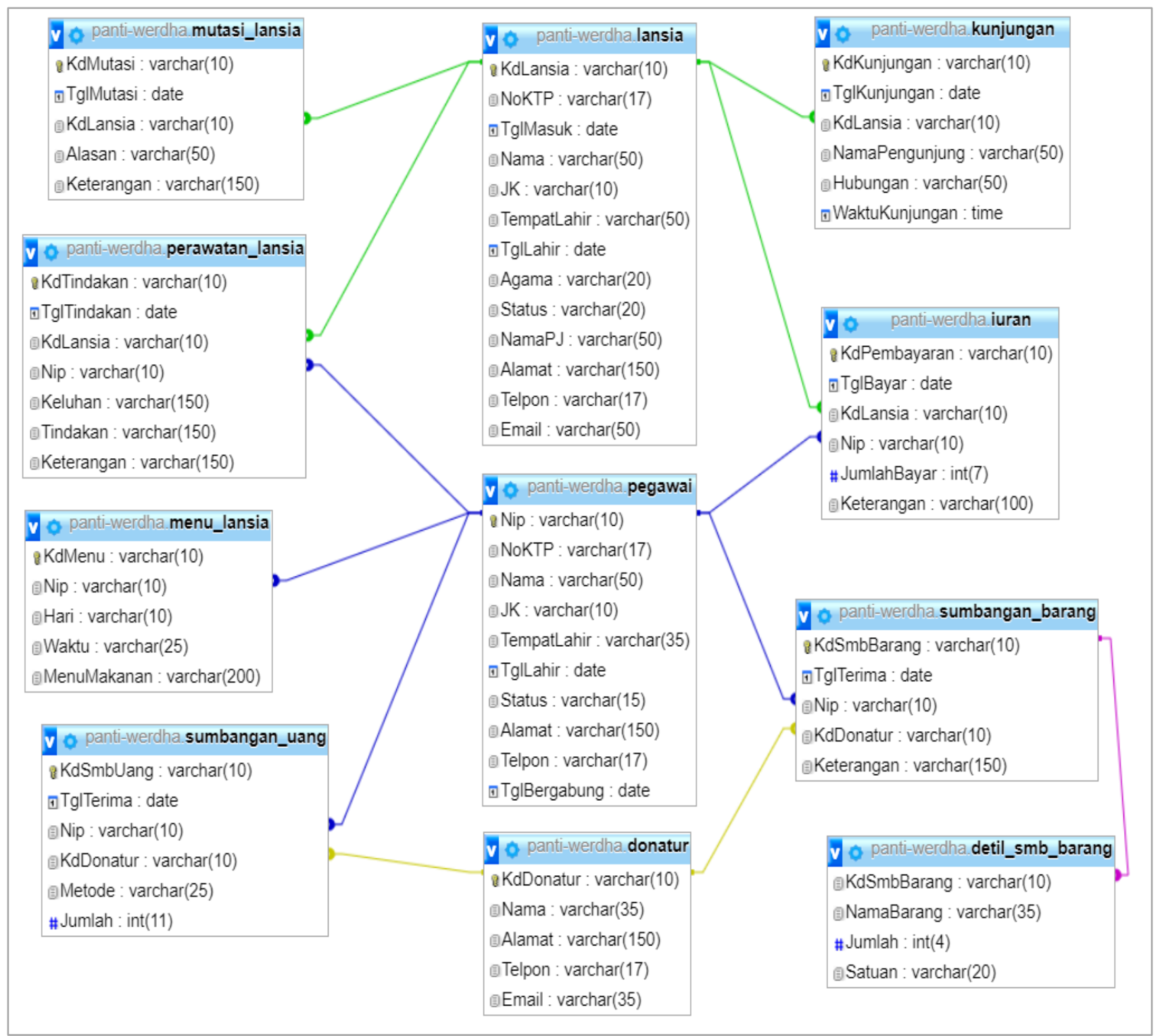

Gambar 12. Hasil Rancangan Basis Data Layanan Panti Werdha.

\section{KESIMPULAN}

Hasil dari penelitian ini adalah sebuah model rancangan basis data relasional yang dapat digunakan untuk menampung data serta menjawab kebutuhan pengelolaan informasi yang diharapkan oleh panti werdha. Metode DBLC memberikan tahapan yang sistematis sehingga mempermudah proses perancangan basis data yang sesuai dengan kebutuhan. Penelitian ini merupakan pengembangan dari penelitian sebelumnya dimana ditambahkan beberapa entitas untuk kebutuhan informasi terkait kunjungan terhadap lansia, menu asupan lansia, tindakan perawatan kesehatan terhadap lansia dan memisahkan jenis sumbangan dari donatur (barang dan uang). Diharapkan dengan adanya rancangan ini para pengembang perangkat lunak dapat melihat gambaran umum tentang informasi apa saja yang dibutuhkan dalam pengembangan sistem informasi panti werdha.

\section{UCAPAN TERIMA KASIH}

Penulis mengucapkan banyak terima kasih atas dukungan morel serta materi dari civitas akademika Universitas Katolik Musi Charitas dan juga pengelola jurnal Jutisi sehingga artikel jurnal ini dapat diselesaikan dengan baik. Penulis berharap kiranya artikel ini memberikan kontribusi 
bagi peningkatan manajemen informasi layanan panti werdha serta menambah wawasan bagi para pembacanya.

\section{DAFTAR PUSTAKA}

[1] Atanasia, G. Syarifudin, "Perancangan Database Relasional Data Lansia Panti Jompo Graha Kasih Bapa Kabupaten Kubu Raya," Jurnal INSERT, vol. 1, pp. 25-35, Agustus 2018.

[2] Kraugusteeliana, "Desain Database Aplikasi Monitoring Peralatan dan Bahan Praktikum pada Lab Patologi Klinik FK UPNVJ," JURNAL INFORMATIK, edisi 16, no. 1, pp. 1-10, April 2020.

[3] Nofiyani, "Model Basis Data Untuk Mendukung Sistem Administrasi Pelayanan dan Perbaikan Motor," Simposium Nasional Ilmiah dengan tema: (Peningkatan Kualitas Publikasi Ilmiah melalui Hasil Riset dan Pengabdian kepada Masyarakat), 7 November 2019, pp. 367-375.

[4] D. S. Anggita, "Proses Perencanaan Basis Data Sistem Rekam Medis Rawat Jalan Puskemas," IT Journal, vol. 6, no. 2, pp. 111-123, Oktober 2018

[5] E. Krisnanik, Kraugusteeliana, "Perancangan Model Basis Data Berbasis Pakar Gangguan Rahim dan Kesehatan Janin Pada Wanita Hamil," Seminar Nasional Teknologi Informasi dan Multimedia AMIKOM, 4 Februari 2017, pp. 1-6.

[6] F. S. Handayani, M. P Putri, "Perancangan Basis Data Instrumen Bimbingan Konseling Alat Ungkap Pemahaman Diri Siswa," Citec Journal, vol. 4, no. 2, pp. 128-140, Februari 2017.

[7] (2020) Website Kamus Besar Bahasa Indonesia. [Online].Tersedia https://kbbi.kemdikbud.go.id/.
[8] E. S. Oktaviana, "Hubungan Interaksi Sosial dan Self Efficacy dengan Kesejahteraan Psikologis Lansia yang Tinggal di Pant Wedha", Skripsi. Fakultas Keperawatan, Program Studi Ners, Universitas Airlangga, Surabaya, 2018.

[9] (2020) Website Departemen Sosial Republik Indonesia. [Online] Tersedia: http://www.bphn.go.id/data/documents/12pmsos019.pdf.

[10] F. Kurniawati, Hubungan Sleep Hygiene dan Kualitas Tidur Lansia. Universitas Erlangga. 2017.

[11] C. J. Date, An Introduction to Database Systems, 8th Edition, Pearson: 2004.

[12] E. Mulyana, A. Wahana, "Rancang Bangun Sistem Basis Data Penelitian Menggunakan Top Down Approach," TELKA: Jurnal Telekomunikasi, Elektronika, Komputasi, dan Kontrol, vol. 3, no. 2 pp. 152-167, November 2017.

[13] T. Connolly, C. Begg, A Practical Approach to Design, Implementation, and Management, 6th Edition. Glasgow: Pearson Education Limited, 2015.

[14] Gat, "Perancangan Basis Data Perpustakaan Sekolah Dengan Menerapkan Model Data Relasional," Citec Journal, vol. 2, no. 4 pp. 304-315, Agustus 2015 - Oktober 2015, ISSN: 2460-4259.

[15] W. S. Prasetya, "Perancangan Model Basis Data Relasional Dengan Metode Database Life Cycle," Seminar Nasional Informatika. 2015 pp. 91-98,

[16] A. Kurnianti, Angguningtyas, R. G. Isnanda, "Perancangan Database Pada Sistem Asessmen Dan Pemetaan Hasil Asessmen Berbasis Tag Sebagai Pembantu Penyusunan Strategi Pembelajaran," Jurnal Ilmiah Semesta Teknika, vol. 20, no.2, pp. 106-115, 2017. 